\title{
Extra-pair paternity in a species with frequent extra-pair courtship feedings, few extra-pair copulations, and male-biased parental care
}

\author{
Mateusz Ledwoń ${ }^{1}$ (D) Patricia Szczys ${ }^{2}$
}

Received: 1 July 2021 / Revised: 22 September 2021 / Accepted: 4 December 2021 / Published online: 16 December 2021

(c) The Author(s) 2021

\begin{abstract}
Patterns of extra pair paternity (EPP) and intraspecific brood parasitism (IBP) were studied in a Whiskered Tern Chlidonias hybrida population characterized by female brood desertion, a high level of extra pair courtship feedings (10\%) and a low level of extra pair copulation (EPC; $0.6 \%$ ). In this study, we used a set of microsatellite loci to analyse parentage in 56 Whiskered Tern families from southern Poland. Depending on the method, we detected that 1.4\%-3.6\% of chicks were sired by an extra-pair male, and extra-pair chicks were present in 3.6\%-8.9\% of broods. IBP was observed in $8.9 \%-14.3 \%$ of broods, corresponding to $3.6 \%-6.4 \%$ of the chicks. The low rate of EPP is in agreement with the hypothesis that in species with high male parental investment, females should avoid EPC. The low level of IBP indicates that intraspecific egg dumping is not a common female strategy in Whiskered Tern, similar to many other colonial waterbird species.
\end{abstract}

Keywords Colonial waterbird $\cdot$ Microsatellite $\cdot$ Paternity $\cdot$ Parental care

\section{Zusammenfassung}

Fremdvaterschaften bei einer Vogelart mit häufigen Fremdbalzfütterungen, wenigen Fremdkopulationen und bei der die Männchen den Großteil der Jungenaufzucht übernehmen

Wir untersuchten die Verteilung von Fremdvaterschaften (engl.: extra-pair paternity, EPP) und innerartlichem Brutparasitismus (engl.: intraspecific brood parasitism, IBP) bei einer Population der Weißbart-Seeschwalbe Chlidonias hybrida, einer Vogelart, bei der die Weibchen die Gelege verlassen und welche sich durch häufige Fremdbalzfütterungen $(10 \%)$ sowie ein geringes Maß an Fremdkopulationen (0,6\%; engl.: extra-pair copulation, EPC) auszeichnet. Für diese Studie nutzen wir eine Reihe von Mikrosatelliten-Loci, um die Verwandtschaftsverhältnisse von 56 Weißbart-SeeschwalbenFamilien aus Südpolen zu analysieren. Abhängig von der Methode stellten wir fest, dass 1,4-3,6 \% der Küken von einem fremden Männchen stammten und dass 3,6-8,9 \% der Bruten Küken fremder Väter enthielten. IBP konnte bei 8,9-14,3 \% der Bruten beobachtet werden und entsprach 3,6-6,4 \% der Küken. Die niedrige Rate von EPP steht im Einklang mit der Hypothese, dass bei Arten mit hoher Beteiligung der Männchen an der Jungenaufzucht die Weibchen EPC vermeiden sollten. Das geringe Maß an IBP deutet darauf hin, dass das Ablegen von Eiern in die Nester fremder Artgenossen bei der WeißbartSeeschwalbe keine verbreitete weibliche Strategie ist, ähnlich wie bei vielen anderen koloniebrütenden Wasservogelarten.

\section{Introduction}

Communicated by S. Bouwhuis.

Mateusz Ledwoń

Ledwon@isez.pan.krakow.pl

1 Institute of Systematics and Evolution of Animals, Polish Academy of Sciences, Kraków, Poland

2 Eastern Connecticut State University, Windham, CT, USA
Extra-pair paternity (EPP) - paternity by any male other than the mother's pair-bonded male and intraspecific brood parasitism (IBP) — brood parasitism in which parasite and host are of the same species, are common in birds. These concepts have led to a paradigm shift in our understanding of the evolution of reproductive strategies (Petrie and Møller 1991; Chaine et al. 2015). Now, evidence has accumulated that the social and genetic mating systems of many species are different. EPP has been found in more than $75 \%$ 
of surveyed socially monogamous bird species (Wink and Dyrcz 1999; Neudorf 2004; Griffith et al. 2002). In monogamous birds, the average rate of EPP is on the order of $10 \%$ of offspring and $20 \%$ of broods (Griffith et al. 2002), but in some passerines the EPP rate exceeds $50 \%$ of all offspring (Dixon et al. 1994). However, extensive variation in EPP among species and populations within species is well documented (Arnold and Owens 2002; Griffith et al. 2002). Intraspecific brood parasitism (IBP) has been reported in more than 200 species, but is likely to be higher, as it can often only be detected by genetic analyses (Yom-Tov 2001). IBP is highest in precocial species but is also common in colonial breeders (Yom-Tov 1980, 2001; de Valpine and Eadie 2008). In some species, it is a widespread behaviour: in American Coot Fulica americana $41 \%$ of pairs are parasitized (Lyon 2003), and in colonially breeding Cliff Swallow Petrochelidon pyrrhonota, the percentage of nests with parasitic eggs may be as high as 33\% (Brown and Bomberger Brown 1996).

Although many hypotheses have been proposed to explain variation in EPP and IBP (e.g. Arnold and Owens 2002; Griffith et al. 2002; Neudorf 2004) among species and populations, the mechanisms driving these behaviours are still being debated (Hsu et al. 2014; Forstmeier et al. 2014). Phylogenetic analysis has shown that majority of interspecific variation in EPP and IBP can be explained by phylogeny (Arnold and Owens 2002). High EPP rates are associated with high rates of adult mortality and reduced parental care, whereas high IBP rates are connected with high fecundity rates and inexpensive parental care. Variation at the population or individual level in EPP and IBP is more likely to be based on differences in current ecological and genetic factors (Petrie and Kempenaers 1998; Andersson and Åhlund 2000, 2001). With regard to ecological factors, breeding density may be an important factor at the species level (Westneat and Sherman 1997).

At the level of the individual, by siring extra-pair young, males increase their reproductive success without incurring the costs of parental care. The benefit of EPP to females is less clear, however; while not increasing the number of offspring that they produce, it may include (1) indirect fitness benefits through better genes, and (2) direct material benefits by trading copulation for food with extra-pair males (e.g. Tryjanowski and Hromada 2005). Indirect genetic benefits could be good paternal genes and genetic compatibility of maternal and paternal genomes (Kempenaers 2007; Puurtinen 2009; Arct et al. 2015). More intriguingly, the adaptiveness of EPP has been questioned in some comparative analyses, with a maladaptive or random scenario proposed as alternative (Forstmeier et al. 2014).

Intraspecific brood parasitism has been viewed as an alternative reproductive strategy used by females to enhance their breeding success without incurring the costs of parental care. In some species, females are capable of doubling their reproductive success by combining brood parasitism with normal nesting (Andersson and Åhlund 2000, 2001).

Gulls and terns, i.e. the family Laridae (order Charadriiformes), are colonial waterbirds. EPP and/or IBP has been examined in only 7 (7\%) of the 97 species in this family. Despite the fact that they breed in large and dense colonies, the EPP rate in these birds is usually low. In Western Gull Larus occidentalis, Black-legged Kittiwake Rissa tridactyla, and Black Tern Chlidonias niger, no EPP was found (Gilbert et al. 1998; Helfenstein et al. 2004; Shealer et al. 2014). However, in Common Gull Larus canus and Whiskered Tern Chlidonias hybrida, EPP involved $8 \%$ and $12 \%$ of broods, respectively (Bukacińska et al. 1998; Minias et al. 2014). Studies of EPP involving more than one population of the same species are rare. In two populations of Common Tern Sterna hirundo, the EPP rate in broods was very low- $0 \%$ and 3\% (González-Solis et al. 2001; Griggio et al. 2004). Interestingly, two European populations of Black-headed Gull Chroicocephalus ridibundus differed significantly in EPP rate- $0 \%$ and 33\% of broods (Ležálová-Piálková 2011; Indykiewicz et al. 2017). The IBP rate in larids is rather low and was not found in three of seven studied species (Bukacińska et al. 1998; González-Solis et al. 2001; Griggio et al. 2004; Helfenstein et al. 2004; Indykiewicz et al. 2017). In Whiskered Tern, the IBP rate was $10 \%$ of broods (Minias et al. 2014). Three populations of Black-headed Gull differed strongly in terms of the IBP rate-10\%, 17\% and 34\% of the brood (Duda et al. 2008; Ležalová-Piálková and Honza 2008; Indykiewicz et al. 2017).

Whiskered Tern is a semi-precocial, socially monogamous, colonial waterbird species, with a high level of parental investment (Gochfeld et al. 2016; Ledwoń and Neubauer 2017; Chambon et al. 2020). Both mates incubate, brood and feed their chicks. Among the Laridae, Whiskered Tern has a unique system of parental care. Almost all females in this species desert their offspring during the chick-rearing and post-fledging periods (Ledwoń and Neubauer 2017). After female desertion, males continue parental care for the next few weeks at least. Males intensify their deliveries of food to their offspring to compensate for the female's absence. To date, EPP and IBP in Whiskered Tern have been studied molecularly in only one population, in central Poland, where the EPP rate was $8 \%$ of the offspring (Minias et al. 2014). However, that study was based on only a small sample; furthermore, it was not known whether female desertions occurred in that population, and other behavioural traits were not studied (see below).

We studied a population breeding in southern Poland exhibiting a high frequency of Extra Pair Courtship Feedings (EPCFs). Visits of extra-pair males that attempted to exchange food for copulation were $10 \%$ of all male visits. However, in most cases females did not trade copulation for 
food with them, instead attempting to snatch or swindle food from extra-pair males (Ledwoń and Neubauer 2018). Only two copulations $(0.6 \%)$ were observed between an extrapair male and a visited female. Therefore, we hypothesize that due to the high investment by males in parental care in our population (Ledwoń and Neubauer 2017), the potential loss of paternal care should be a reason why females do not engage in EPCs (Pierce and Lifjeld 1998; Blomqvist et al. 2002; Küpper et al. 2004, but see Houston and McNamara 2002). However, some studies at the within-species level have shown that the observed intensity of EPC does not correlate with the EPP rate (Birkhead and Møller 1995; Birkhead and Pizzari 2002). For example, individuals of both sexes can choose more secluded spots for extra-pair than for within-pair copulations so as to avoid the costs of being discovered by their partner-physical punishment, reduced parental investment or divorce (Valera et al. 2003; Tryjanowski et al. 2007). In this study, we analyse the parentage of Whiskered Tern to compare the effective EPP with the low level of EPC in a population with female offspring desertion. We also studied the rate of IBP in this species.

\section{Methods}

\section{Field work}

Fieldwork was conducted between June to mid-August in 2006-2010 and 2013-2015, in Whiskered Tern breeding colonies on carp pond complexes in the northern part of the Upper Vistula Valley $(50.000198,19.435818)$, southern Poland (for a detailed description of the study area, see Ledwoń et al. 2013, 2014). From 2 to 16 families were studied for EPP and IBP in 1 year, on average it was seven families per year. The birds were studied in 14 colonies, in each colony from one to seven randomly chosen families were inspected. In studied colonies from about $5 \%-20 \%$ of nests were tested for EPP and IBP. The most distant colonies were $26 \mathrm{~km}$ apart. The number of nests in the colonies varied between 20 and 60. All the colonies were situated in open habitats since the majority of nests were constructed on floating leaves of Fringed water lily Nymphoides peltata. The nests were located close to each other, usually around one to several metres apart.

Monitoring of all the nests started during the early stages of incubation (up to about the 10th day after egg laying). We erected plastic mesh fences around the monitored nests with eggs to prevent the chicks from escaping until they had fledged (for a detailed description of the enclosure and trap, see Ledwoń et al. 2015, 2016). Colonies were visited twice a week to study breeding success, trap adults and take blood samples from chicks and adults. Adults were trapped with a roof trap, on nests from about the 10th day after clutch completion to the downy chick period (around 5th day of chicks life). We tried to catch both parents of each nest. A blood sample (c. $0.2 \mathrm{ml})$ was taken from both adults and chicks from the tarsus vein. If a chick died before blood could be taken, we took tissue from the carcass. Blood and tissue was stored in $98 \%$ ethanol at $-20{ }^{\circ} \mathrm{C}$ until processing. The mean size of the sampled broods was $2.5 \pm 0.08$ [se] chicks (range $1-3)$. In most cases, we sampled entire broods $N=36(64 \%)$, but in the remaining broods $N=20$ (36\%), eggs were lost during incubation, chicks were predated before blood could be sampled, or DNA extraction was impossible because the egg or embryo were in an advanced stage of putrefaction.

\section{Molecular analysis}

DNA was extracted using a Qiagen DNEasy Kit (Qiagen, Valencia, California, USA) or Blood Mini Kit (A\&A Biotechnology, Poland). A total of 242 individuals comprising 56 broods were genotyped at six autosomal microsatellite loci, previously developed from Red-billed Gull Larus novaehollandiae (RBG13, 18, 27, 29; Given et al. 2002) and Roseate Tern Sterna dougallii (AAT27, AAC20; Szczys et al. 2005; Table 1). The polymerase-chain reaction (PCR) was conducted in $25 \mu \mathrm{L}$ reactions containing $2 \times$ Promega GoTaq PCR MasterMix, $1.0 \mu \mathrm{M}$ primers and $5 \mu \mathrm{L}$ genomic DNA
Table 1 Microsatellite marker characteristics as calculated in GenAIEx (Peakall and Smouse 2012)

\begin{tabular}{llllllllll}
\hline Locus & $\mathrm{N}$ & $\mathrm{N}_{\mathrm{A}}$ & \multicolumn{1}{l}{$\mathrm{H}_{\mathrm{o}}$} & $\mathrm{H}_{\mathrm{e}}$ & $\mathrm{F}$ & $\mathrm{NE}-1 \mathrm{P}$ & $\mathrm{NE}-2 \mathrm{P}$ & NE-PP & fnull \\
\hline RBG29 & 102 & 6 & 0.520 & 0.548 & 0.052 & 0.861 & 0.729 & 0.582 & -0.0006 \\
RBG27 & 100 & 8 & 0.620 & 0.658 & 0.058 & 0.759 & 0.592 & 0.410 & 0.0802 \\
RBG18 & 94 & 10 & 0.617 & 0.533 & -0.157 & 0.849 & 0.687 & 0.508 & -0.0880 \\
RBG13 & 101 & 7 & 0.158 & 0.706 & 0.776 & 0.730 & 0.561 & 0.380 & 0.6314 \\
AAT27 & 100 & 5 & 0.550 & 0.711 & 0.226 & 0.681 & 0.506 & 0.321 & 0.1645 \\
AAC20 & 97 & 11 & 0.464 & 0.790 & 0.413 & 0.570 & 0.392 & 0.203 & 0.2258 \\
Mean & 99 & 7.8 & 0.488 & 0.658 & 0.228 & - & - & - & - \\
\hline
\end{tabular}

Number of adults genotyped $(\mathrm{N})$; number of alleles $\left(\mathrm{N}_{\mathrm{A}}\right)$; observed heterozygosity $\left(\mathrm{H}_{\mathrm{o}}\right)$; expected heterozygosity $\left(\mathrm{H}_{\mathrm{e}}\right)$; inbreeding fixation index $(\mathrm{F})$. CERVUS (Marshall et al. 1998) calculated the non-exclusion probabilities (NE) for the first parent sampled (1P), the second parent sampled (2P) and the parent pair (PP), and estimated the frequency of null alleles (fnull) 
extract. The standard thermocycling conditions were: initial denaturation step at $94.0^{\circ} \mathrm{C}$ for $5 \mathrm{~min}$, followed by 30 cycles of $94{ }^{\circ} \mathrm{C}$ for $30 \mathrm{~s}, 50-55{ }^{\circ} \mathrm{C}$ for $30 \mathrm{~s}, 72{ }^{\circ} \mathrm{C}$ for $1 \mathrm{~min}$, and a final $72{ }^{\circ} \mathrm{C}$ extension for $10 \mathrm{~min}$. PCR products were diluted in formamide loading dye, and genotypes were resolved on a 4300 DNA Analyzer alongside a panel of five individuals serving as an inter-gel allele standard and an IRDye infrared dye size standard (LiCOR). Alleles were identified by SAGA G2 software (LiCOR). Where amplifications failed, replicate PCR was conducted-in all cases individual loci consistently failed to amplify in those individuals (see null alleles below). To ensure that a male and a female were always assigned as social parents during the fieldwork we molecularly sexed all trapped pairs. For a detailed description of the method, see (Goławski et al. 2016).

\section{Data analysis}

Microsatellite diversity (number of alleles, observed and expected heterozygosity, inbreeding coefficient) was characterized by GenAIEx 6.5 (Peakall and Smouse 2012) using only sampled adults $(N=102)$. CERVUS 3.0 (Marshall et al. 1998) was used to estimate deviation from Hardy-Weinberg Equilibrium, the frequency of null alleles, and non-exclusion probabilities for single parent maternity or paternity and for parent-pairs by including all 242 sampled individuals.

We considered a single mismatched locus to be the result of mutation or a null allele. Using CERVUS, we conducted a parentage simulation using both strict (95\%) and relaxed $(85 \%)$ criteria to exclude social parents as genetic parents and thus identify EPP or IBP events. This provided an upperbound estimate of EPP/IBP frequency. For all chicks mismatching at least one parent by at least two loci and with negative LOD scores (the natural log of the overall likelihood ratio), we also calculated the cumulative probability of resemblance ( $\mathrm{P}_{\mathrm{RCum}}$; Eq. 4; Ibarguchi et al. 2004). Negative LOD scores indicated that the candidate parent was less likely to be the true parent than not the true parent (Marshall et al. 1998). The index $\mathrm{P}_{\mathrm{RCum}}$ was the probability that two individuals shared at least one copy of any allele at all loci; it provided greater power to probe whether social parents and offspring were likely to share multilocus genotypes if they were not related. This measure provided a lower-bound estimate of EPP/IBP frequency.

\section{Results}

The CERVUS parentage simulation analysis involved 140 chicks and 102 adults. The mean polymorphic information content was 0.61 and the non-exclusion probability was 0.157 for the first parent, 0.033 for the second parent, and 0.003 for parent pairs. Both social parents were sampled in
46 broods, only the social father was sampled in 7 broods (17 chicks) and only the social mother was sampled in 3 broods ( 9 chicks).

Chicks mismatching their social father at two or more loci while matching their social mother were considered as EPP, and five chicks from five different broods met these criteria (Table 2). Chicks mismatching only their social mother at two or more loci while matching their social father were considered as IBP, and six chicks from six different broods met these criteria (Table 2). Three chicks from two broods mismatched both social parents at two or more loci; they were considered to be the result of IBP through egg-dumping (Table 2).

Implementation of the Ibarguchi method ( $\mathrm{P}_{\mathrm{RCum}}$; Eq. 4) predicated on Mendelian inheritance and (where appropriate by locus) potential for null alleles (Table 1) showed that three out of five EPP chicks had probabilities of resemblance with the social father of $<0.008$ and should not be considered as EPP (Table 2). Four out of nine IBP chicks had probabilities of resemblance with social parent(s) ranging from 0.0003 to 0.0098 and were thus not considered as IBP (Table 2).

Three chicks that mismatched their social mother at a single locus and whose social father was not sampled had $\mathrm{P}_{\mathrm{RCum}}$ values from 0.006 to 0.02 excluding null alleles and from 0.0006 to 0.0016 including null alleles, making it likely that these chicks were the biological offspring of their mothers. Similarly, three different chicks that mismatched their social father at a single locus and whose social mother was

Table 2 Summary of extra-pair paternity (EPP), intraspecific brood parasitism (IBP), and egg dumping frequency implementing two methods

\begin{tabular}{lll}
\hline & $n(\%)$ CERVUS & $n(\%) \mathrm{P}_{\mathrm{RCum}}$ \\
\hline EPP $^{1}$ chicks & $5(3.6)$ & $2(1.4) ; 4(2.8)^{4}$ \\
EPP broods & $5(8.9)$ & $2(3.6)$ \\
IBP $^{2}$ chicks & $6(4.3)$ & $5(3.6)$ \\
Egg dump chicks $\left.^{3}\right)$ & $3(2.1)$ & $0(0)^{4}$ \\
IBP broods & $6(10.7)$ & $5(8.9)$ \\
(Egg dump broods) & $2(3.6)$ & $0(0)^{4}$ \\
\hline
\end{tabular}

CERVUS (Marshall et al. 1998) identified mismatched social parents $(\mathrm{LOD}<0)$ and provided an upper limit for EPP/IBP frequency. The index $\mathrm{P}_{\mathrm{RCum}}$ (Ibarguchi et al. 2004) provided a lower limit EPP/ IBP frequency using the probability of multilocus genotype matching between social parent and offspring $(P>0.0098)$. A total of 140 chicks from 56 broods were tested

${ }^{1}$ Chicks mismatch social father but match social mother at two or more loci

${ }^{2}$ Chicks mismatch social mother but match social father at two or more loci

${ }^{3}$ Chicks mismatch both social parents at two or more loci

${ }^{4} \mathrm{P}_{\mathrm{RCum}}$ method estimates two chicks (one brood) classified as egg dump by CERVUS became EPP 
not sampled had $\mathrm{P}_{\mathrm{RCum}}$ values from 0.008 to 0.01 excluding null alleles and from 0.0002 to 0.004 including null alleles, making it likely that these chicks were the biological offspring of their fathers.

Pooling these results to provide upper- and lower-bound estimates, we determined the EPP rate in the studied Whiskered Tern population at between 1.4 and $3.6 \%$ of chicks and in $3.6 \%-8.9 \%$ of broods, and IBP in $3.6 \%-6.4 \%$ of chicks and $8.9 \%-14.3 \%$ of broods (Table 2 ).

\section{Discussion}

In this study, the EPP rate in Whiskered Tern did not exceed $5 \%$ of chicks and $10 \%$ of broods. Our findings were similar to the EPP rate estimated in a population of Whiskered Tern from central Poland, where EPP was found in $8 \%$ of chicks and in $12 \%$ of broods (Minias et al. 2014). So far, betweenpopulation variation in the EPP rate has been reported for a small number of avian species, mostly passerines. In most studies the differences were not great (e.g. Charmantier and Blondel 2003; Maher et al. 2017), as was found in Whiskered Tern (Minias et al. 2014; this study), although in some species differences between populations are shown to be high-0 vs 33\% (Ležálová-Piálková 2011; Indykiewicz et al. 2017).

In Black Tern, a species closely related to and co-distributed with Whiskered Tern in Europe, no EPP was detected (Shealer et al. 2014). Thus, EPP rates in the genus Chlidonias generally appear to be in accordance with average estimates found in both larids and a wider group of colonial waterbirds, where the EPP rate is rather low (as reviewed by Indykiewicz et al. 2017). No evidence for EPP was found in almost half of all studied colonial waterbird species, and the average EPP rate was estimated at less than 5\% of offspring.

The EPP rate in Whiskered Tern found in our study and in that by Minias et al. (2014) was only slightly higher than in Kentish Plover Charadrius alexandrinus, a species with a similar breeding system involving female desertion. In Kentish Plover, the EPP rate studied in different populations was found to be between 0 and $4.1 \%$ of broods and 0 and $1.6 \%$ of chicks (Maher et al. 2017). The observed low EPP rate in Whiskered Tern stands in agreement with the suggestion that in species with high paternal investment, females might be constrained by their reliance on male cooperation during biparental care, which might discourage them from seeking EPCs (Küpper et al. 2004; Arnqvist and Kirkpatrick 2005). It was demonstrated that the level of male care during chick provisioning was negatively correlated with EPP (Møller and Birkhead 1993; Ball et al. 2017). During biparental care in Whiskered Tern, males provide their chicks with c. $25 \%$ more food (kJ) than females (Ledwoń and Neubauer 2017), so any reduction of parental care by males could be costly for females. Male parental care is important in species with female desertion, and the costs of reduced parental care can be high when the remaining parent is unable to compensate fully (Székely and Williams 1995; Székely and Cuthill 1999; Lessells 2012). Therefore, females should avoid EPC if this leads to a reduction in care on the part of their social mate. However, this behaviour was not studied in Whiskered Tern.

The estimated EPP rate in this study was only slightly higher than the EPC rate $(0.6 \%)$ documented in this population-only two of 328 successful copulations were EPC (Ledwoń and Neubauer 2017). This difference could be the result of postcopulatory sexual selection-the choice of sperm by the female and competition of the ejaculates of different males over fertilization (Birkhead and Pizzari 2002; Wagner et al. 2004). Extra-pair paternity mainly occurs as a result of three behaviours: forced EPCs, rapid mate switching, and unforced EPCs (Birkhead et al. 1990; Birkhead and Møller 1995). Since both within-pair and extra-pair copulations are under female control in Whiskered Tern, no successful forced EPC occurred, and mate switching close to the egg-laying period was not noted (Ledwoń 2010; Ledwoń and Neubauer 2018). EPP in this species can therefore be assumed to be the result of female EPCs, which they accept or solicit, a rather common phenomenon in birds (Birkhead 1998; but see Adler 2010). Females in our study area have plenty of opportunities to engage in EPC, since they remain alone on the nesting platform for about $65 \%$ of the time and visits by extra-pair males are common (Ledwoń 2010; Ledwoń and Neubauer 2018). But even though such visits are frequent, the majority of females do not engage in EPC. In this, as in many other colonial species, frequent copulation is used as a paternity guard, since males spend most of their time foraging and delivering food to their females and cannot protect their females from EPCs at the same time (Birkhead 1998).

As in other larids, our study population experienced low rates of IBP: this is usually between 0 and $10 \%$ of broods, occasionally reaching 20\% (Bukacińska et al. 1998; González-Solis et al. 2001; Griggio et al. 2004; Helfenstein et al. 2004; Duda et al. 2008; Piálková 2008; Minias et al. 2014; Indykiewicz et al. 2017). Our results are consistent with those obtained for other populations of Whiskered Tern. IBP was found in $10 \%$ of broods in a population breeding in central Poland (Minias et al. 2014), and in a French population, IBP was reported in $9 \%$ of broods where the presence of parasitic eggs was estimated using the analysis of intra-clutch variation in egg morphology (Paillisson et al. 2008). The levels of intraspecific brood parasitism found in Whiskered Tern may be facilitated by periods of nonattendance at nests by both pair members during the preincubation period, as suggested by Paillisson et al. (2008); in that French population, nests were unattended for $3 \%$ of the time. In our population, parents left the nesting platform 
unattended on average for only $0.9 \%$ of the time (MLunpublished data). One case of forced IBP was observed (ML-unpublished data), when a parasitic female pushed the host female off the nest and laid an egg, which means that the absence of both mates is not necessary for IBP to occur in Whiskered Tern. In all nests with IBP, three eggs were present, which is the typical clutch size in this species. Thus, it is likely that parasitic females dump their egg before the clutch in the host nest is completed so that the host females stop laying when the total clutch size reaches the normal, as typical behaviour in indeterminate layers (e.g. Andersson and Eriksson 1982). A male and a female were present in all the nests with IBP, which indicates that there were no female-female pairs.

By determining parentage in two ways, this study produced a range estimate of EPP and IBP. CERVUS (Marshall et al. 1998) is a powerful tool for genetic mating system studies, especially those for which parentage is unknown, where parental care is handled by mothers only, and where the aim is to assign paternity from a large pool of potential candidates. In our study, we sampled both social parents for most broods and aimed to exclude social fathers or mothers using the complementary approach of Ibarguchi et al. (2004). $\mathrm{P}_{\mathrm{RCum}}$ calculated the probability that the social parent and offspring share the documented alleles (including null alleles when frequent) if they were not actually related. Chicks designated as EPP or IBP occurred when that probability was relatively high $(P>0.0098)$. Thus, in our study, fourteen chicks mismatched one or more social parents at two or more loci and had negative LOD scores thus were designated as EPP or IBP under the CERVUS criteria but those numbers decreased to nine using the Ibarguchi method.

Acknowledgements We greatly appreciate the cooperation of the fish farmers concerned. We would like to thank Agnieszka Ledwoń, Robert Gwiazda and Nataly Atamas for their assistance in the field, Kasper Chlebowicz for his help in lab with molecular sex determination and Peter Senn for his linguistic guidance. Mateusz Ledwoń received partial financial support within the framework of a project from the Ministry of Science and Higher Education of Poland (30402731/0904). The fieldwork was carried out by permission of the Local Ethical Committee, the Ministry of the Environment and the General Directorate for Environmental Protection. Dominique Dubois, Erin Conn, and Mackenzie Roberts assisted with lab analyses funded by CSU-AAUP research funding granted to Patricia Szczys.

Author contributions Study concept, fieldwork, biological sampling, molecular sexing, and manuscript preparation: ML; genotyping and parentage analysis and manuscript preparation: PS.

Funding Partial financial support within the framework of a project from the Ministry of Science and Higher Education of Poland (30402731/0904) to M. Ledwoń; CSU-AAUP Faculty Research grant to P. Szczys.

Data availability Genotypes available upon request.
Code availability N/A.

\section{Declarations}

\section{Conflict of interest N/A.}

Ethics approval Handling of animals, biological sampling, and export/ import of biological samples were all conducted within the parameters of appropriate permits in Poland and USA.

Open Access This article is licensed under a Creative Commons Attribution 4.0 International License, which permits use, sharing, adaptation, distribution and reproduction in any medium or format, as long as you give appropriate credit to the original author(s) and the source, provide a link to the Creative Commons licence, and indicate if changes were made. The images or other third party material in this article are included in the article's Creative Commons licence, unless indicated otherwise in a credit line to the material. If material is not included in the article's Creative Commons licence and your intended use is not permitted by statutory regulation or exceeds the permitted use, you will need to obtain permission directly from the copyright holder. To view a copy of this licence, visit http://creativecommons.org/licenses/by/4.0/.

\section{References}

Adler M (2010) Sexual conflict in waterfowl: Why do females resist extrapair copulations? Behav Ecol 21:182-192

Andersson M, Åhlund M (2000) Host-parasite relatedness shown by protein fingerprinting in a brood parasitic bird. Proc Natl Acad Sci USA 97:13188-13193

Andersson M, Åhlund M (2001) Protein fingerprinting a new technique reveals extensive conspecific brood parasitism. Ecol 82:1433-1442

Andersson M, Eriksson MOG (1982) Nest parasitism in goldeneyes Bucephala clangula: some evolutionary aspects. Am Nat 120:1-16

Arct A, Drobniak SM, Cichoń M (2015) Genetic similarity between mates predicts extrapair paternity - a meta-analysis of bird studies. Behav Ecol 26:959-968

Arnold KE, Owens IPF (2002) Extra-pair paternity and egg dumping in birds: life history, parental care and the risk of retaliation. Proc R Soc Lond Ser B 269:1263-1269

Arnqvist G, Kirkpatrick M (2005) The evolution of infidelity in socially monogamous passerines: the strength of direct and indirect selection on extrapair copulation behavior in females. Am Nat 165:S26-37

Ball AD, van Dijk RE, Lloyd P, Pogány Á, Dawson DA, Dorus S, Bowie RCK, Burke T, Székely T (2017) Levels of extra-pair paternity are associated with parental care in penduline tits (Remizidae). Ibis 159:449-455

Birkhead TR (1998) Sperm competition in birds: mechanisms and function. In TR Birkhead, Møller AP (eds) Sperm competition and sexual selection. Academic Press.

Birkhead TR, Burke T, Zan R, Hunter FM, Krupa AP (1990) Extra-pair paternity and intraspecific brood parasitism in wild zebra finches Taeniopygia guttata, revealed by DNA fingerprinting. Behav Ecol Sociobiol 27:315-324

Birkhead TR, Møller AP (1995) Extra-pair copulation and extra-pair paternity in birds. Anim Behav 49:843-848

Birkhead TR, Pizzari T (2002) Postcopulatory sexual selection. Nat Rev Genet 3:262-273 
Blomqvist D, Andersson M, Küpper C, Cuthill I, Kis J, Lanctot R, Sandercock B, Székely T, Wallander J, Kempenaers B (2002) Genetic similarity between mates and extra-pair parentage in three species of shorebird. Nature 419:613-615

Brown CR, Bomberger Brown M (1996) Coloniality in the Cliff Swallow. University of Chicago Press, Chicago

Bukacińska M, Bukaciński D, Epplen JT, Lubjuhn SKP, T, (1998) Low frequency of extra-pair paternity in Common Gulls (Larus canus) as revealed by DNA fingerprinting. J Ornithol 139:413-420

Chaine AS, Montgomerie R, Lyon BE (2015) Sexual conflict arising from extrapair matings in birds. Cold Spr Harb Perspect Biol 7(3):a017590. https://doi.org/10.1101/cshperspect.a017590

Chambon R, Latraube F, Bretagnolle V, Paillisson JM (2019) Sex-specific contributions to reproduction in Whiskered tern Chlidonias hybrida colonies of varying breeding density. Ardeola 67:113-125

Charmantier A, Blondel J (2003) A contrast in extra-pair paternity levels on mainland and island populations of Mediterranean blue tits. Ethol 109:351-363

de Valpine P, Eadie JM (2008) Conspecific brood parasitism and population dynamics. Am Nat 172:547-562

Dixon A, Ross D, O’Malley SLC, Burke T (1994) Paternal investment inversely related to degree of extra-pair paternity in the reed bunting. Nature 371:698-700

Duda N, Chętnicki W, Waldeck P, Andersson M (2008) Multiple maternity in black-headed gull Larus ridibundus clutches as revealed by protein fingerprinting. J Avian Biol 39:116-119

Forstmeier W, Nakagawa S, Griffith SC, Kempenaers B (2014) Female extra-pair mating: adaptation or genetic constraint? Trends Ecol Evol 29:456-464

Gilbert L, Burke T, Krupa A (1998) No evidence for extra-pair paternity in the western gull. Mol Ecol 7:1549-1552

Given AD, Mills JA, Baker AJ (2002) Isolation of polymorphic microsatellite loci from the red-billed gull (Larus novaehollandiae scopulinus) and amplification in related species. Mol Ecol Notes 2:416-418

Gochfeld M, Burger J, Kirwan GM, Garcia EFJ (2016) Whiskered Tern (Chlidonias hybrida) In: del Hoyo J, Elliott A, Sargatal J, Christie DA, de Juana E (ed) Handbook of the Birds of the World Alive. Cornell Lab of Ornithology, Ithaca, NY, USA. https://doi.org/10.2173/bow.whiter2.01

Goławski A, Kasprzykowski Z, Ledwoń M, Mróz E (2016) Brood sex ratio in expansive and non-expansive tern species in east-central Poland. Bird Study 63:31-36

González-Solís J, Sokolov E, Becker PH (2001) Courtship feedings, copulations and paternity in common terns, Sterna hirundo. Anim Behav 61:1125-1132

Griffith SC, Owens IPF, Thuman KA (2002) Extra pair paternity in birds: a review of interspecific variation and adaptive function. Mol Ecol 11:2195-2212

Griggio M, Matessi G, Marin G (2004) No evidence of extrapair paternity in a colonial seabird, the common tern (Sterna hirundo). Italian J Zool 71:219-222

Helfenstein F, Tirard C, Danchin E, Wagner R (2004) Low frequency of extra-pair paternity and high frequency of adoption in BlackLegged Kittiwakes. Condor 106:149-155

Houston AI, McNamara JM (2002) A self-consistent approach to paternity and parental effort. Phil Trans R Soc B 357:351-362

Hsu YH, Schroeder J, Winney I, Burke T, Nakagawa S (2014) Costly infidelity: low lifetime fitness of extra-pair offspring in a passerine bird. Evolution 68:2873-2884

Ibarguchi G, Gissing GJ, Gaston AJ, Boag PT, Friesen VL (2004) Male-biased mutation rates and the overestimation of extrapair paternity: problem, solution, and illustration using thick-billed murres (Uria lomvia, Alcidae). J Hered 95:209-210
Indykiewicz P, Podlaszczuk P, Minias P (2017) Extra-pair paternity in the black-headed gull: Is it exceptional among colonial waterbirds? Behav 154:1081-1099

Kempenaers B (2007) Mate choice and genetic quality: A review of the heterozygosity theory Adv Study Behav 37:189-278

Küpper C, Kis J, Kosztolanyi A, Székely T, Cuthill I, Blomqvist D (2004) Genetic mating system and timing of extra-pair fertilizations in the Kentish Plover. Behav Ecol Sociobiol 57:32-39

Ledwoń M (2010) Male and female partitioning in parental care in Whiskered Tern Chlidonias hybrida. PhD dissertation, Polish Academy of Sciences, Kraków. (In Polish)

Ledwoń M, Betleja J, Neubauer G (2015) An effective method for trapping both parents and chicks in whiskered terns (Chlidonias hybrida) and its impact on breeding success. Waterbirds 38:290-295

Ledwoń M, Betleja J, Neubauer G (2016) Different trapping schemes and variable disturbance intensity do not affect hatching success of whiskered terns Chlidonias hybrida. Bird Study 63:136-140

Ledwoń M, Betleja J, Stawarczyk T, Neubauer G (2014) The Whiskered Tern Chlidonias hybrida expansion in Poland: the role of immigration. J Ornithol 155:459-470

Ledwoń M, Neubauer G (2017) Offspring desertion and parental care in the Whiskered Tern Chlidonias hybrida. Ibis 159:860-872

Ledwoń M, Neubauer G (2018) True deception during extra-pair courtship feeding: cheating Whiskered Tern Chlidonias hybrida females perform better. J Avian Biol 49:1-6. https://doi.org/10. $1111 /$ jav.01503

Ledwoń M, Neubauer G, Betleja J (2013) Adult and pre-breeding survival estimates of the Whiskered Tern Chlidonias hybrida breeding in southern Poland. J Ornithol 154:633-643

Lessells CM (2012) Sexual conflict. In Royle NJ, Smiseth PT, Kö1like M (eds) The evolution of parental care: 150-170. Oxford: Univ. Press.

Ležalová-Piálková R, Honza M (2008) Responses of Black-headed Gulls Larus ridibundus to conspecific brood parasitism. J Ornithol 149:415-421

Ležalová-Piálková R (2011) Molecular evidence for extra-pair paternity and intraspecific brood parasitism in the black-headed gull. J Ornithol 152:291-295

Lyon BE (2003) Egg recognition and counting reduce costs of avian conspecific brood parasitism. Nature 422:495-499

Maher K, Eberhart-Phillips L, Kosztolanyi A, dos Remedios N, Carmona-Isunza M, Cruz-López M, Zefania S, St Clair J, Alrashidi M, Weston M, Serrano-Meneses MA, Krüger O, Hoffman J, Székely T, Burke T, Küpper C (2017) High fidelity: extra-pair fertilisations in eight Charadrius plover species are not associated with parental relatedness or social mating system. J Avian Biol 48:910-920

Marshall TC, Slate JBKE, Kruuk LEB, Pemberton JM (1998) Statistical confidence for likelihood-based paternity inference in natural populations. Mol Ecol 7:639-655

Minias P, Minias A, Dziadek J (2014) Occurrence of extra-pair paternity and intraspecific brood parasitism in the Whiskered Tern Chlidonias hybrida. Bird Study 61:130-134

Møller AP, Birkhead TR (1993) Certainty of paternity covaries with paternal care in birds. Behav Ecol Sociobiol 33:261-268

Neudorf DLH (2004) Extra-pair paternity in birds: understanding variation among species. Auk 121:302-307

Paillisson J-M, Latraube F, Marion L, Bretagnolle V (2008) Indirect evidence for conspecific brood parasitism in the colonial whiskered tern (Chlidonias hybrida). CR Biologies 331:559-567

Peakall R, Smouse PE (2012) GenAlEx 6.5: genetic analysis in Excel. Population genetic software for teaching and research-an update. Bioinform 28:2537e2539. 
Petrie M, Kempenaers B (1998) Extra-pair paternity in birds: explaining variation between species and populations. Trends Ecol Evol 13:52-58

Pierce EP, Lifjeld JT (1998) High-paternity without paternityassurance behavior in the Purple Sandpiper, a species with high paternal investment. Auk 115:602-612

Petrie M, Møller AP (1991) Laying eggs in others' nests: Intraspecific brood parasitism in birds. Trends Ecol Evol 6:315-320

Puurtinen M, Ketola T, Kotiaho JS (2009) The good-genes and compatible-genes benefits of mate choice. Am Nat 174:741-752

Shealer D, Devbhandari S, Garcia Mendoza MG (2014) Evidence for genetic monogamy but low mate retention in the North American Black Tern (Chlidonias niger surinamensis). Waterbirds 37:129-135

Szczys P, Hughes CR, Kesseli RV (2005) Novel microsatellite markers used to determine the population genetic structure of the endangered Roseate Tern, Sterna dougallii, in Northwest Atlantic and Western Australia. Conserv Genetics 6:461-466

Székely T, Williams TD (1995) Costs and benefits of brood desertion in female kentish plovers, Charadrius alexandrinus. Behav Ecol Sociobiol 37:155-161

Székely T, Cuthill IC (1999) Brood desertion in Kentish plover: the value of parental care. Behav Ecol 10:191-197

Tryjanowski P, Antczak M, Hromada M (2007) More secluded places for extra-pair copulations in the great grey shrike Lanius excubitor. Behav 144:23-31
Tryjanowski P, Hromada M (2005) Do males of the great grey shrike, Lanius excubitor, trade food for extrapair copulations? Anim Behav 69:529-533

Valera F, Hoi H, Krištín A (2003) Male shrikes punish unfaithful females. Behav Ecol 14:403-408

Wagner R, Helfenstein F, Danchin E (2004) Female choice of young sperm in a genetically monogamous bird. Proc R Soc Lond Ser B 271(Suppl 4):S134-137

Westneat DF, Sherman PW (1997) Density and extra-pair fertilizations in birds: a comparative analysis. Behav Ecol Sociobiol 41:205-215

Wink M, Dyrcz A (1999) Mating systems in birds: a review of molecular studies. Acta Ornithol 34:91-109

Yom-Tov Y (1980) Intraspecific nest parasitism in birds. Biol Rev 55:93-108

Yom-Tov Y (2001) An updated list and some comments on the occurrence of intraspecific nest parasitism in birds. Ibis 143:133-143

Publisher's Note Springer Nature remains neutral with regard to jurisdictional claims in published maps and institutional affiliations. 